\title{
MISCELLANEA
}

\section{NOVÉ AKVIZICE RUKOPISNÉ SBÍRKY KNIHOVNY NÁRODNÍHO MUZEA. NÁKUPY Z LET 2014-2019}

\author{
Zdeněk Mužík (Praha)
}

Především díky péči a píli Michala Dragouna a jeho spolupracovníků snad nelze Knihovně Národního muzea vyčítat, že by v posledních letech zanedbávala odborné zpracovávání své rukopisné sbírky. ${ }^{1}$ I přes toto úsilí však KNM v katalogizaci rukopisů stále zůstávají dva velké dluhy. Jednak jde o akvizice novověkých rukopisů zařazených do fondu po roce 1916, popsané většinou pouze v provizorním katalogu oddělení rukopisů a starých tisků $\mathrm{KNM},{ }^{2}$ jednak o rukopisy podchycené pouze $\mathrm{v}$ Soupisu pořizeném před více než sto lety Františkem M. Bartošem, který již nedostačuje dnešním požadavkům na jejich popis. ${ }^{3}$

Není záměrem a ani v možnostech tohoto článku tento dluh umenšit - jeho nápravou může pochopitelně být pouze vznik nového kompletního soupisu - nicméně jeho snahou je tento dluh alespoň dále nezvyšovat a poskytnout badatelské obci informace o nových přírůstcích, $v$ tomto prrípadě o devíti rukopisech zakoupených do KNM mezi lety 2014 a 2019. Tři z nich pochází od jednotlivců, kteří se svou nabídkou oslovili Národní muzeum. Zbylých šest bylo zakoupeno společně z antikvariátu Ztichlá klika. ${ }^{4}$ Součástí této akvizice je také jediný „kompaktnějšši“ celek, čtyři knihy z pozůstalosti českého a rakouského právníka a politika Jana Jaroslava Becka (1812-1895) (II E 46, IV B 26, VI F 72, VIII B 12). Dvě z nich také vykazují jistou spojitost se zámeckou knihovnou hrabat Chorinských, respektive s knihovnou svobodných pánů z Walldorfu, která je její součástí (IV B 26, VI F 72), což bude v budoucnu vhodné ještě ověřit. Pokud jde o obsah jednotlivých rukopisů, převažuje mezi nimi právo (IV B 26, VI F 72, VIII B 12), po němž následuje historiografie (IV D 82, VIII D 36). Po jednom exempláŕi má zastoupení hospodářství (II E 46), magie (XI B 67), žalmy a modlitby (XVIII G 1) a filozofie (X B 33).

Popis rukopisů vychází ze Zásad popisu rukopisư ${ }^{5}$ a katalogizační praxe KNM, v některých ohledech je však podrobnější, než by podle nich bylo nutné. Přihlédnuto bylo také $\mathrm{k}$ moderním katalogům $\mathrm{s}$ větším podílem novověkých rukopisů. ${ }^{6}$ Práce se neobešla bez cizí pomoci, a za různé větší či menší rady bych tak chtěl v abecedním pořadí poděkovat Michalu Dragounovi, Jiřímu Dufkovi, Karlu Křenkovi, Petru Maškovi, Kateřině Spurné, Richardu Šípkovi, Janě Tvrzníkové, Kateřině Volekové a Blance Zilynské.

\section{E 46}

Čechy, XVII ${ }^{1}$, pap., XII + 308 pp., $18,5 \times 15$ cm, vazba chybí

Původní paginace provedena inkoustem ve vnějším horním rohu textového zrcadla, s výjimkou pag. 296 označené nahoře uprostřed a neočíslovaných pp. 207 bis a 273. Chyba v paginaci: pag. 206 vynechána, pag. 207 bis. Textové zrcadlo vyznačeno inkoustem jednou linkou, při horním okraji dvěma, mezi nimiž je živé záhlaví, vpichy patrné. Pag. II prázdná. $\mathrm{Na}$ konci rukopisu minimálně jeden list chybí. Okraje listů na začátku a v závěru rukopisu mírně natrženy a olámány. Hřbety složek se rozpadají, několik listů uvolněno. Papír místy poškozen korozí inkoustu.

Písmo: jedna písařská ruka píśící českou novogotickou kurzivou, předmluva, nadpisy a část živých záhlaví polokurzivou. Vazba chybí. Na pag. I a na hřbetu fragmenty hnědého

\footnotetext{
1 Jde hlavně o soupis středověkých rukopisů získaných po roce 1916, viz DRAGOUN 2011, a popisy do té doby jen nesystematicky podchycených rukopisných zlomků, viz DRAGOUN - MAREK 2012; BRČÁK et al. 2014; BENEŠ et al. 2015; BROM et al. 2016; DRAGOUN 2017. Mimo popisy rukopisů KNM v různých dílčích studiích jich pak Michal Dragoun několik ročně vytvoří i v rámci digitalizačního programu VISK 6. Pro tento účel vzniklé popisy jsou spolu s jejich digitalizáty dostupné on-line na stránkách http://www.manuscriptorium.com/

2 Jedná se o přepis níže citovaného Soupisu doplněného o jeho opravy a dodatky, interní záznamy i nově vznikající popisy. Vzhledem k proměnlivé kvalitě jednotlivých záznamů však může posloužit pouze jako pomůcka pro základní orientaci. K dispozici je i jeho on-line verze: https://nm2018-cz.nm.netservis.cz/file/7779a5859eb18elaaced4e0a83602ef9/8625/Bartos.pdf

3 Soupis byl dokončen v roce 1917, vydán byl ale až později. Viz BARTOŠ 1926; BARTOŠ 1927.

Stručně je zmínil MUCHKA 2019, s. 76.

ZÁSADY.

'J Jmenovitě DOKOUPIL - ŠTACHOVÁ 2011; SVOBODOVÁ 2012.
} 
papíru, snad jde o pozůstatky papírové vazby. Složky šité dlouhým stehem na čtyři otvory. Hřbet druhotně zajištěn papírem pravděpodobně z 18 . století s nečitelným fragmentem nápisu na vnitřní straně.

$\mathrm{Na}$ pag. II exlibris KNM se současnou signaturou. Na pp. II, 308 černé kruhové razítko KNM. Na pag. 308 přírůstkové číslo KNM 4/2019 a KNM2 6100. Do KNM byl rukopis zakoupen 5. 4. $2019 \mathrm{z}$ antikvariátu Ztichlá klika a dle sdělení antikváře Jana Placáka byl součástí knihovny Jana Jaroslava Becka (1812-1895), českého a rakouského právníka a politika. Viz též zde popsané rukopisy IV B 26; VI F 72; VIII B 12.

I-XII, 1-308: [Jan Brtvín z Ploškovic, Mikuláš Artemisius, Jan Hus:] „Hospodář. Knížka velmi užitečná, zavírajíc v sobě předně navedení života křest’anského, jak by ti, kteříž v světě nad jinými panují, sami sebe i sobě poddaně [!] spravovati měli; potom gruntovní správu a pořádek všelijakého hospodářství, zvláště při panstvích a zbožích, potřebná pánům, kteříž veliké statky na zemi mají. Vydaná vůbec před lety XLVII a nyní opět $\mathrm{s}$ přidáním jiné kratší správy o témž znovu vytlačené mistra Daniele Adama Veleslavína léta Páně 1587 etc.“

Opis stejnojmenného tisku (K01308). Na pag. I titulní list opsaný i s impresem, na pp. III-XII predmluva, na pp. 1-76 „Přední stránka knižky této o zpưsobu a životu křestanském“, na pp. 77-207 „Druhá strana knižky této o hospodářstvi" ", oboje od Jana Brtvína z Ploškovic, na pp. 208-295 „Jiná kratši správa jednomu každému pánu velmi užitečná, ... “ od Mikuláše Artemisia (1495-1556), na pp. 296-308 „, Traktát o odúmrti'“, na rozdíl od tisku je zde jméno autora, Jana Husa, vynecháno a dopsáno až mladší rukou tužkou. Konec spisu v rozsahu necelé strany tisku chybí.

\section{B 26}

Morava, XVI², pap., III + 70 ff., $31 \times 20,5 \mathrm{~cm}$, vazba chybí

Původní foliace inkoustem v pravém horním rohu. Textové zrcadlo vyznačeno inkoustem zleva a zprava. Ff. Ir-IIv, IIIv a $32 \mathrm{v}$ prázdná. $Z$ poslední složky dochován jen vnější dvoulist. Další neurčitý počet složek na konci rukopisu pravděpodobně chybí. Knižní blok silně poškozen vlhkostí a plísní, patrné zatekliny. Listy se rozpadají, z mnohých části chybí. Při vnějším okraji listů skvrny po korozi. Ztráty textu při vnějších okrajích a zvláště při horních rozích. Ff. I-II seříznuta.

Písmo: psáno jednou písařskou rukou českou novogotickou kurzivou, nadpisy a začátky článků polokurzivou, latina humanistickou polokurzivou. Opravy a doplňky textu soudobou rukou. Vazba chybí, rukopis vložen do desek z lepenky a dvou archů papíru. Stopy korozních produktů poukazují na možné kování nedochované vazby. Na hřbetě pozůstatky šití na pět vazů. Za ff. 3, 17 a 49 vložen čistý půllist papíru z 20. století.

$\mathrm{Na}$ přední desce lepenkového obalu inkoustem rukou 19.-20. století „Kniha půhonů a nálezů“, v levém horním rohu nalepen štítek z růžového papíru s číslem „1407“, který snad souvisí s knihovnou Jana Jaroslava Becka či její částí (viz také zde II E 46; VI F 72; VIII B 12). Na fol.
IIIr „Ex bibliotheca illustrissimi [!] domini Ignatii comitis Waldorff 1733“ a „C. Modestus Moravus z Mezř́iče nad Bečvú pod Rožnovem capucinus“, oboje rukou téhož (viz DOKOUPIL - ŠTACHOVÁ 2011, s. 12-13). Na fol. Ir exlibris KNM se současnou signaturou. Na ff. IIIr, 70v černé kruhové razítko KNM. Na fol. 70v přírůstkové číslo KNM 4/2019 a KNM2 6099. Do KNM byl rukopis zakoupen 5. 4. $2019 \mathrm{z}$ antikvariátu Ztichlá klika a dle sdělení antikváře Jana Placáka byl součástí knihovny Jana Jaroslava Becka. Viz též zde II E 46; VI F 72; VIII B 12.

IIIr, 1r-70v: „Extrakt ze všech register zemských půh[onných] Margkrabství moravského [všech pů]honúv, na kteréž se nálezy panské [při prá]vě zemském olomouckém od léta Páně čtrnáctistého pátého až do léta patnáctistého devadesátého čtvrtého staly“

Opisy olomouckých pưhonů a nálezů, presněji jejich výběr z let 1405-1412 z knihy se znamením střely (ff. 1r-17r), $z$ let 1412-1420 z knihy se znamením slunce (ff. 17v-32r), $z$ let 1437-1448 z knihy se znamenim ostrve (ff. 33r-52v) a z let 1463-1466 z knihy se znamením měsice (ff. 53r-70v), z niž část chybí. Ff. 1r-4v psána převážně latinsky, poté jen přiležitostnè. Podle Čádovy typologie sborniků moravských půhonů a nálezů lze tento extrakt zar̆adit do skupiny A (viz $\check{C} A$ AA 1958). Edice všech olomouckých knih půhonů a nálezů ze zmíněných knih: BRANDL 1872, s. 103-404; BRANDL 1873, s. 365-630; BRANDL 1880; BRANDL 1882.

\section{D 82}

Čechy, XVIII med., pap., 132 pp., 21,5 × 17 cm, vazba mladší

Původní paginace provedena inkoustem ve vnějším horním rohu, na pp. 119-129 opravena dobovou rukou. Četné stránkové reklamanty. Textové zrcadlo vyznačeno jednou linkou inkoustem. Živá záhlaví na pp. 1-81 s názvy kapitol, na pp. 82-132 nedůsledně s variantami názvu díla. Na konci rukopisu chybí minimálně jedna složka. Ztráty okrajů listů dolity papírem. Zašpiněné rohy, především dolní. Koroze inkoustu v některých iniciálách a nadpisech po pag. 40.

Písmo: psáno pravděpodobně jednou písařskou rukou M. W. P. S. (?) (pag. 68) novogotickou polokurzivou s proměnlivým modulem písma, latinská slova humanistickou polokurzivou. Místy opravy a doplňky provedené inkoustem a tužkou několika rukama 18. a 19. století. Výzdoba: ornamentální iniciály přes 3-13 řádků (obvykle kolem osmi) na pp. $1,3,16,18,21,22,26,27,28,30,31,36,38,39$, $41,44,47,50,55,59,69,81,86,88$. Pletencové viněty na pp. $15,35,68$. Rubrikace. Měkká papírová vazba z roku 2015. Složky šité dlouhými stehy. Rukopis byl restaurován v roce 2015 Karlem Křenkem v restaurátorské dílně KNM (očištění, dolití papíru, nové sešití knižního bloku, nová vazba). Záznam o restaurování přilepen na zadním přídeští.

Na předním přídeští exlibris KNM se současnou signaturou, tatáž signatura tužkou rovněž na hřbetě a na přední části vnitřní obálky. Na pag. 132 černé kruhové razítko KNM. Na zadní části vnitřní obálky modré kruhové razítko KNM, současná signatura, př́růstkové číslo KNM 1/2014 a KNM2 6058. Do KNM byl rukopis zakoupen 5. 12. 2014 od Petra Prokeše z Běchar. 


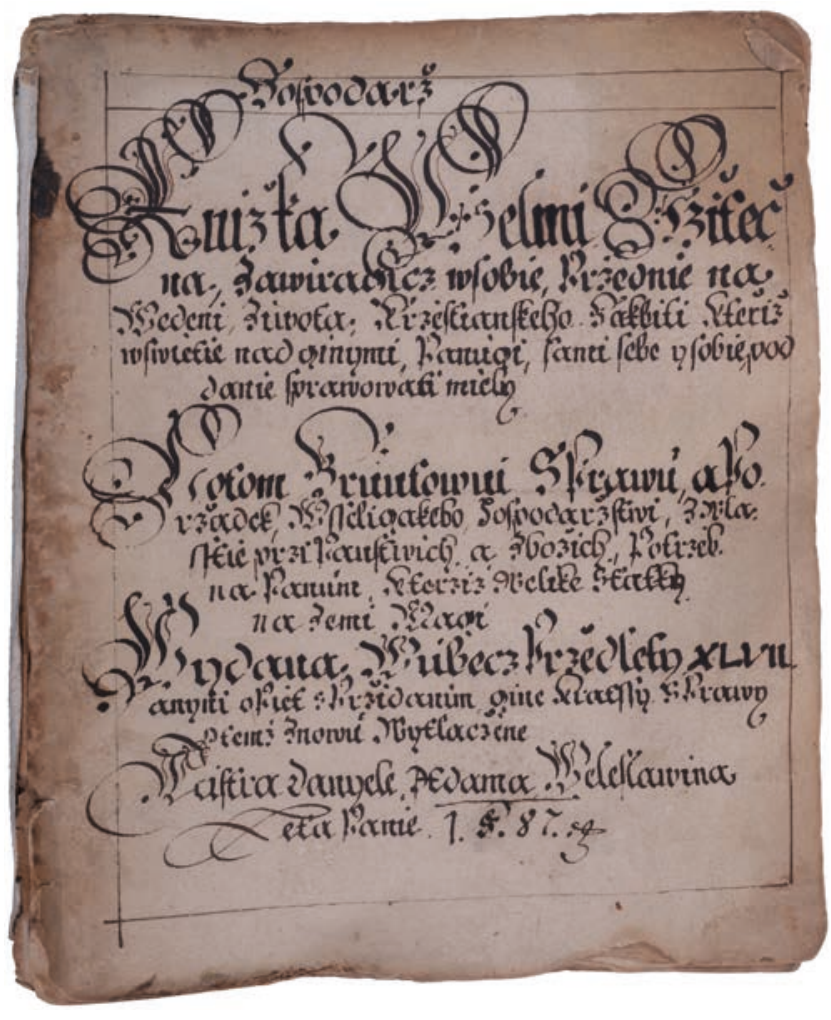

Obr. 1. Jan Brtvín: Hospodář. Praha, Knihovna Národního muzea, oddělení rukopisů a starých tisků, sign. II E 46, pag. I, titulní list. Foto: KNM.

1-81: [Jindřich Václav Zyvalda: Dejm města Kouřima, někdy čtverou vůni z sebe vydávající]

Opis stejnojmenného tisku vydaného pravděpodobně v pražské jezuitské tiskárně roku 1659 nebo 1665 (K19028), v současnosti známého pouze z jediného neúplného exempláre. Titulní list chybí. Na pp. 1-3 „,Dedicatoria“, na pp. 3-15 „První vůně města Kouřima. Starožitnosti“, na pp. 16-35 „Druhá vưně města Kouřima. Vzáctný města zakladatel“, na pp. 36-58 „Třetí vůně města Kourima. Knížetstvi“", na pp. 59-68, „Čtvrtá odporná vioně města Kouřima“ (v živém záhlaví kapitoly „odporná“ opravováno na „čtvrtá“), na pp. 69-81,,Odporná vưně města Kouřima“. Na pag. 68 kolofon (?) „,M. W. P. S. 1746“.

82-132: „Letopisové neb všeliké paměti královského krajského města Kouřima", [část]

Letopisné záznamy z let 1608-1747, na konci neurčitá část chybí. Na pp. 99, 100, 103, 105, 107, 126 a 127 několika rukama pozdější záznamy k letům 1844, 1806, 1771, 1768, 1778, 1853, 1875, 1811 a 1859. Rukopis stejného názvu opis pořizený roku 1937 s pozdějšimi doplňky - se nachází v SOkA Kolín, knihovna, sign. 10849 R 1159. Je součástí opisu Zyvaldova Dejmu, zněním se však od zde popisovaného rukopisu misty lehce liší.

\section{F 72}

Morava, 1690, pap., 136 pp., $20 \times 15,5$ cm, vazba dobová

Původní paginace inkoustem nahoře uprostřed. Chyby v paginaci: vynechána pag. 101, pag. 136 bis. Reklamant na pag. 124. Textové zrcadlo vyznačeno slepou linkou zleva

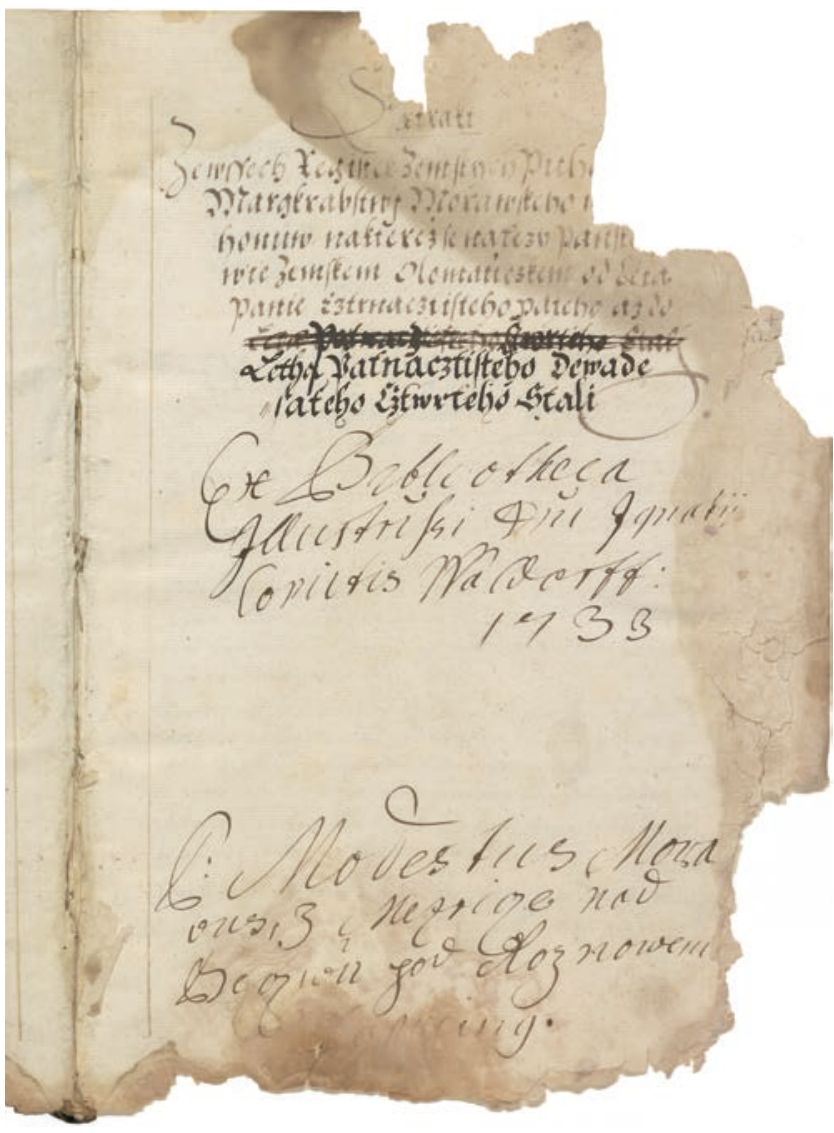

Obr. 2. Extrakt ze všech register zemských půhonných Markrabství moravského. Praha, Knihovna Národního muzea, oddělení rukopisů a starých tisků, sign. IV B 26, fol. Illr, titulní list s exlibris Gotfrýda Ignáce (I.) z Waldorffu a katalogizační záznam kapucína Modesta. Foto: KNM.

a zprava. V druhé polovině bloku degradace papíru ve středu složek.

Písmo: psáno jednou písařskou rukou, latinskou humanistickou kurzivou, německé a české úryvky novogotickou kurzivou. Četné zběžněji psané přípisky a opravy autora textu, Carla Ferdinanda von Schertz (identifikace podle rukopisu MZK, CH-RKP-88, viz též DOKOUPIL - ŠTACHOVÁ 2011, č. 80, 89 a 102). Výzdoba: pletencové viněty na pp. 1, 7, 8, 10, 15, 124, 136 bis. Měkká papírová vazba z mramorovaného papíru. Potah hřbetu chybí, hřbet druhotně přetřen bílou barvou. Šití na trri vazy. Vpředu i vzadu tři volné listy předsádky. Desky lehce poškozeny, hřbet mírně deformován.

$\mathrm{Na}$ hřbetě inkoustem stará signatura „G 7 49“ (?), na přední desce růžový papírový štítek s číslem „258“ (srov. zde též IV B 26; VIII B 12). Na zadním přídeští tužkou číslo „29:8“. Stejný typ značení se nachází minimálně u dvou rukopisů z knihovny hrabat Chorinských z Veselí nad Moravou (MZK, CH-RKP-79; CH-RKP-88). Na versu posledního listu přední předsádky tužkou poznámka ,gut zu benutzen“" s podpisem „Beck“. Rukopis byl součástí knihovny Jana Jaroslava Becka, viz zde též II E 46; IV B 26; VIII B 12. Na předním přídeští tužkou inventární záznam antikvariátu Ztichlá klika a exlibris KNM se současnou signaturou. Na pp. 2, 136 černé kruhové razítko KNM. Na pag. 136 


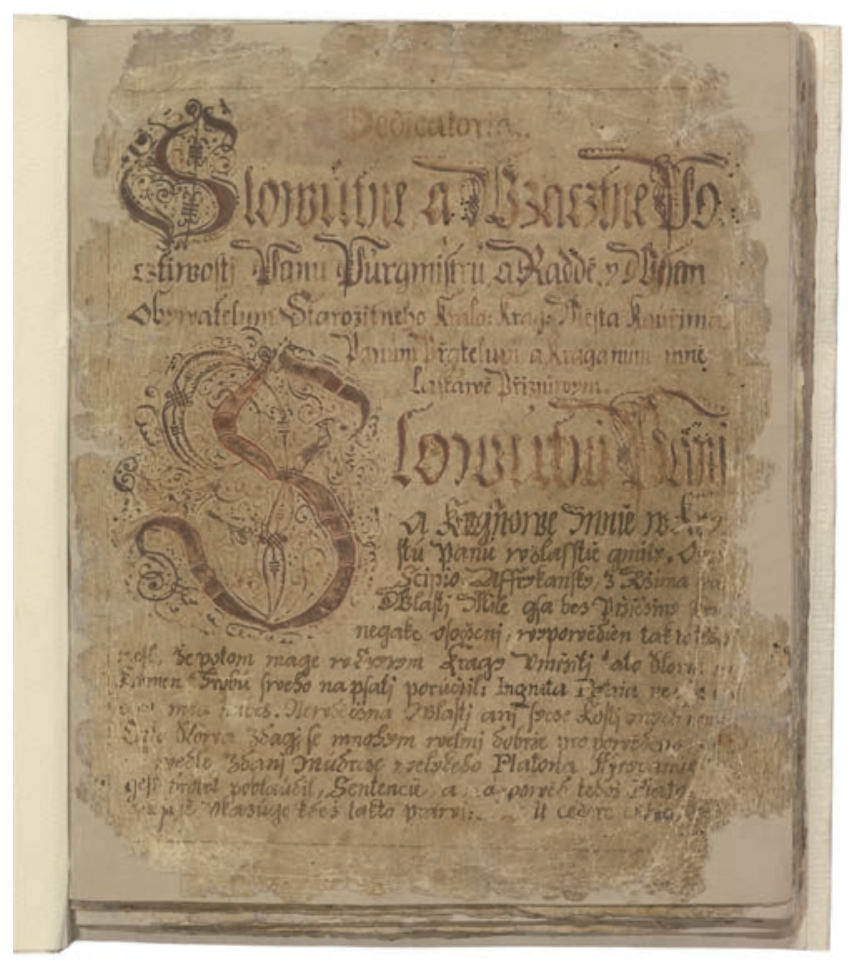

Obr. 3. Jindřich Václav Zyvalda: Dejm města Kouřima; Letopisové města Kouřima. Praha, Knihovna Národního muzea, oddělení rukopisů a starých tisků, sign. IV D 82, pag. 1, začátek dedikace se dvěma ornamentálními iniciálami S. Foto: KNM.

přírůstkové číslo KNM 4/2019 a KNM2 6103. Do KNM byl rukopis zakoupen 5. 4. $2019 \mathrm{z}$ antikvariátu Ztichlá klika.

1-136: Carl Ferdinand von Schertz: „Varietates undetriginta juris Regii provincialis inclyti Marchionatus Moraviae ac juris Justinianaei adsertis ubivis corrollariis delectim libatae a Carolo Ferdinando equite de Schertz reverendissimi et celsissimi principis Caroli D. G. episcopi Olomucensis consiliario judiciorum feudalium assesore. Aerae salutis MDCXC“"

Právní pojednání o rozdilech moravského a rrimského práva z pera moravského právnika a historika Carla Ferdinanda von Schertz († 1724), dnes známého především kvůli jeho dilu Magia posthuma zabývajícímu se problematikou vampyrismu (k jeho osobé a dílu viz MAIELLO 2012). Spis je uvozen oslavnou básní na Moravu „Propylaeum. Ave, fave, fove Morave" (pp. 3-7), dedikaci nejmenovaným censorüm (pag. 8), předmluvou ke čtenáři (pp. 9-10) a jeho součástí je i prídavek o rozdilech v lenním právu „Appendicium seu aliquot differentiae consuetudinum feudalium in Moravia atque consuetudinum feudalium communium seu Longobardiae“ (pp. 125-136 bis). Snad se jedná o podklad pro tisk, $k$ němuž však nedošlo. Bibliografie Carla Ferdinanda von Schertz tento spis neeviduje (MAIELLO 2012, s. 221-222).

\section{B 12}

Čechy, XVII ex., pap., I + 106 ff., $30 \times 20$ cm, vazba dobová

Moderní foliace provedena tužkou po deseti v pravém horním rohu během katalogizace (2020). Místy stránkové

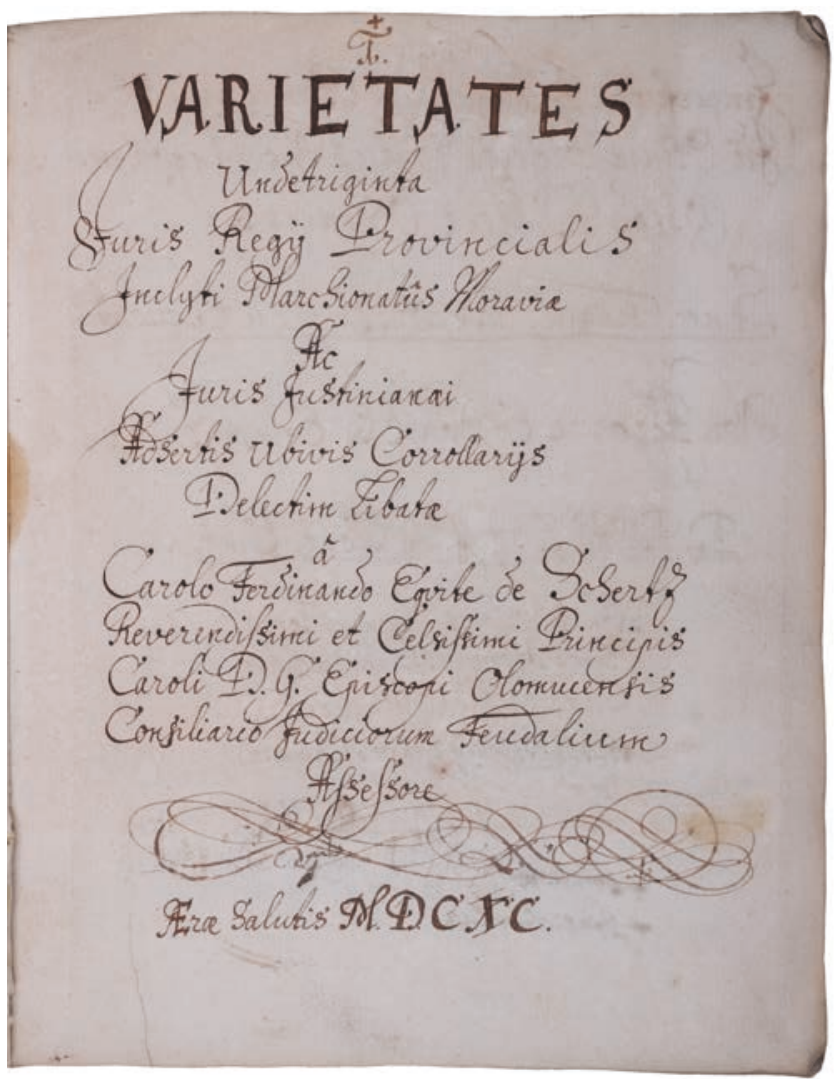

Obr. 4. Carl Ferdinand von Schertz: Varietates undetriginta juris Regii provincialis inclyti Marchionatus Moraviae ac juris Justinianaei. Praha, Knihovna Národního muzea, oddělení rukopisů a starých tisků, sign. VI F 72, pag. 1, titulní list. Foto: KNM.

reklamanty. Textové zrcadlo vyznačeno tužkou zleva a zprava, na ff. 94r-105r navíc jednou linkou vlevo. Fol. I prázdné. Z poslední složky dochován jenom jeden list.

Písmo: psáno jednou písařskou rukou T. FW. německou novogotickou kurzivou, nadpisy novogotickou polokurzivou, latina humanistickou polokurzivou. Polopergamenová vazba, lepenkové desky potažené hnědým papírem se dvěma dvojicemi kožených řemínků k zavazování rukopisu. Žlutý pergamenový hřbet druhotně přetřen bílou barvou. Šití na tři vazy. Červeno-modrá stříkaná ořízka. Okraje desek částečně roztřepeny. Jeden kožený řemínek na zadní desce schází. Zadní drážka a vaz u hlavy knihy prasklé, knižní blok částečně uvolněn z vazby. Na mezivazní přelepy použit fragment českého tisku. Zadní volný list předsádky chybí.

Na hřbetu tužkou číslo „27““, nečitelný fragment seškrábaného textu inkoustem a kousek štítku $\mathrm{z}$ růžového papíru (viz zde též IV B 26; VI F 72). Na fol. 41r dvakrát slepě vyryto „Barterini (?)“. Na předním př́ideští tužkou inventární záznam antikvariátu Ztichlá klika a exlibris KNM se současnou signaturou. Na ff. 1v, 106v černé kruhové razítko KNM. Na fol. 106v přirůstkové číslo KNM 4/2019 a KNM2 6101. Do KNM byl rukopis zakoupen 5. 4. $2019 \mathrm{z}$ antikvariátu Ztichlá klika a dle sdělení antikváře Jana Placáka byl součástí knihovny Jana Jaroslava Becka. Viz též zde II E 46; IV B 26; VI F 72.

1r-24r: [Nálezy brněnského městského práva]

Nálezy méstského práva z Právni knihy mésta Brna. $V$ edici jejich latinského znéní FLODR 1990 odpovidají 
článkům číslo 520-521, 542-543, 524-540, 522-523, 542 (sic!), 544-571 (zkrácený), 572, 571 (sic!), 573-613. Od fol. 9v je u každého článku in margine poznamenáno počáteční slovo jeho latinského znění, obvykle is odkazem na folio. Odkazy na folia i počáteční slova odpovídají tisku Právni knihy vydané v Norimberku u Georga Stuchse kolem roku 1498 (ib01219000).

24r-28v: [Johannes Andreae: Výklad o stromech př́buzenství pokrevního a nepokrevního, část]

České znèní spisu Lectura super arboribus consanguinitatis et affinitatis italského kanonisty Johanna Andreae (cca 1270 až 1348), bez ilustrací. Naff. 24r-28r „,Jak se má čísti strom krevnosti “, naff. 28r-28v ,,Jak se má čisti strom švagrovstvi' "(pouze začátek výkladu, nedopsáno). Spis je rovněž součástí výše citovaného tisku (ib01219000). Edice latinského znění FRIEDBERG - RICHTER 1959, sl. 1427-1436.

29r-105r: [Pavel Kristián z Koldína: Das böhmische Stadtrecht]

Opis tisku německého překladu Koldinových Práv městských Království českého vydaného v Lipsku roku 1614 (VD17 1:041834T). Titulní list a dedikace vynechány. Na ff. 29r-30r ,Index titulorum juris civilis. Ordnung der Titul der Stadtrechten der königlichen Stade Praag“, na ff. 94r-105r ,Ordentlich Register über die gantze Staderechte“. Na fol. 105 r kolofon ,a me vero T. FW. descriptum 1680".

105v-106v: „Copia decreti der königlichen Appellationen ob dem Präger Schloss in Königreich Böheimb an Burgermeister undt Rath der königlichen Stadt Brünn abgangen sub praesentato den 23. Maii anno 1681“

Opis dekretu Rady nad apelacemi purkmistrovi a radě města Brna vydaného na Pražském hradě 4. února 1680, kterým se upravuje postup vymáhání dluhů a exekuci. V obecně adresovaném znění byl vydán v Jan Jakub Weingarten, Codex Ferdinandeo-Leopoldinus ..., Prag: Karel Ferdinand Arnolt 1701, pag. 204, N. 296 (BCBT03020).

\section{D 36}

střední Evropa (Morava?), XVII²-XVIII in., pap., 236 ff., $29,5 \times 19 \mathrm{~cm}$, vazba dobová

Moderní foliace v pravém horním rohu po deseti provedena tužkou během katalogizace (2020). Na ff. 95-171 reklamanty na konci složek, na ff. 198-235 stránkové reklamanty. Textové zrcadlo na ff. 3-196 orámováno tužkou, na ff. 200235 slepou linkou, místy patrné vpichy. Ff. $1 \mathrm{v}-2 \mathrm{v}, 43 \mathrm{r}-44 \mathrm{v}$, 75r-77r, 79r-80v, 83r-84v, 93r-95v, 123v, 143r-144v, $152 \mathrm{r}-153 \mathrm{v}, 154 \mathrm{v}-155 \mathrm{v}, 173 \mathrm{v}-174 \mathrm{v}, 177 \mathrm{r}-178 \mathrm{v}, 180 \mathrm{r}-181 \mathrm{v}$, $183 \mathrm{r}-184 \mathrm{v}, 189 \mathrm{v}-192 \mathrm{r}, 193 \mathrm{v}-196 \mathrm{v}, 197 \mathrm{v}, 199 \mathrm{v}, 235 \mathrm{v}-236 \mathrm{v}$ prázdná.

Písmo: na rukopise se podílely celkem čtyři písařské ruce, všechny píšící humanistickou polokurzivou, v nadpisech na ff. 3r-193r a místy i na ff. 197r-235r majuskule humanistickým kresleným písmem. Ruka A: fol. 1r a př́ípisky passim na ff. $3 \mathrm{r}-92 \mathrm{v}$; ruka $\mathrm{B}$ : ff. $3 \mathrm{r}-92 \mathrm{v}$; ruka C: 96r-193v; ruka D: 197r-235r. Výzdoba: perokresba erbu Orlíků z Lazicka na fol. 1r, jednoduchá pletencová viněta na fol. 92v. Celokožená vazba, lepenkové desky, kožený potah ze stř́kané kưže zdobený slepotiskovým rámem o třech

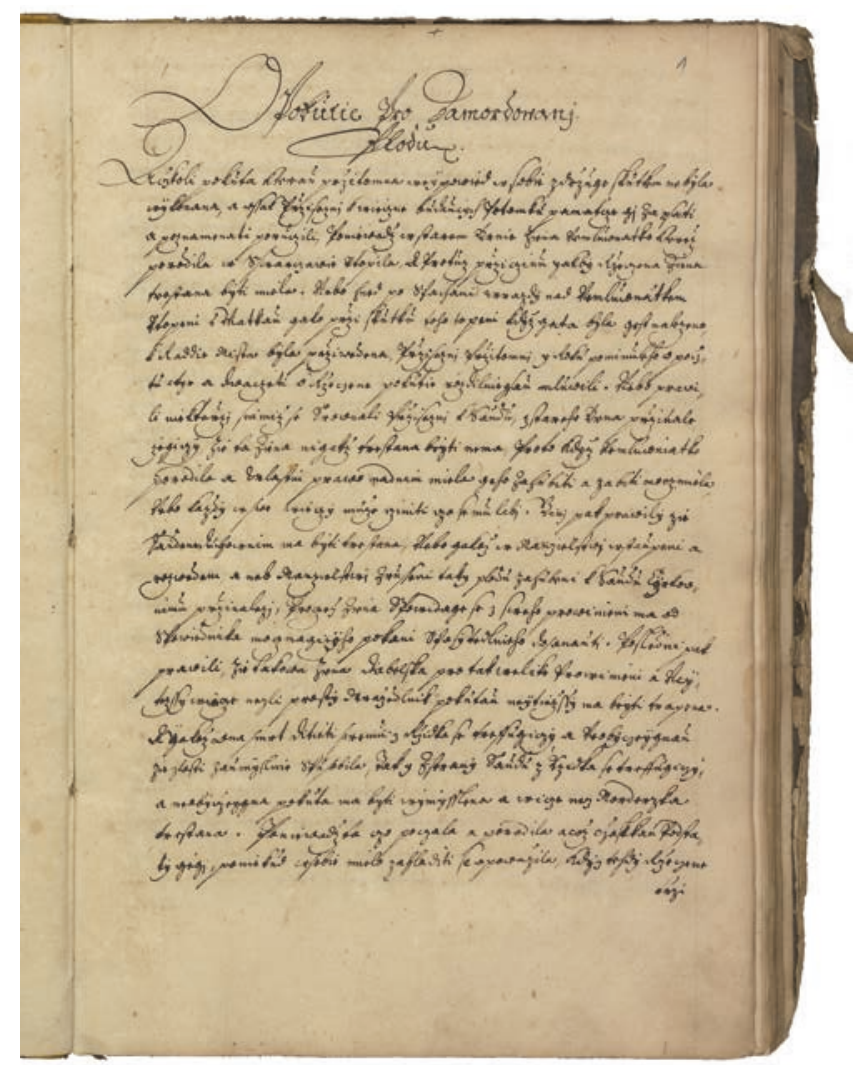

Obr. 5. Nálezy brněnského městského práva; Pavel Kristián z Koldína: Das böhmische Stadtrecht. Praha, Knihovna Národního muzea, oddělení rukopisů a starých tisků, sign. VIII B 12, fol. 1r, první list nálezů. Foto: KNM.

linkách. Šití na šest vazů, lepené kapitálky s pergamenovým jádrem a jednoduchým obšíváním světlou a okrovou nití. Vpředu i vzadu jeden volný list předsádky. Mezivazní pole hřbetu zdobena ornamentální slepotiskovou ražbou, zachovány stopy po zlacení. Do fol. 94 pozůstatky zlacení ořízky. Na přední desce zbytky přilepeného papíru, na přední i zadní desce několik bílých skvrn. Drobné ztráty potahu desek v rozích, hlavice mírně odtrženy. Prasklá přední vnitřní drážka. Za fol. 153 vložen útržek papíru s fragmentem německého textu psaného německou novogotickou kurzivou 19. století. Za fol. 163 vložen fragment pravděpodobně francouzského listu, dochovány pouze začátky slov na čtyřech řádcích. Za fol. 231 vložen nepopsaný útržek papíru.

$\mathrm{Na}$ hřbetě nalepen papírový štítek $\mathrm{s}$ raženým nápisem „P: ORLICK STAMMENHAVS“, ke kterému je dvakrát inkoustem připsáno číslo „,551“. Na předním přídeští inkoustem „Ex libris Caroli Francisci Orlik 1. b. de Laziska“ a tužkou inventární záznam antikvariátu Ztichlá klika. Na fol. 3r mědirytové heraldické exlibris ,Joh. Bap. Gr. Orlick Freih. von Lazischka“. Na předním přídeští exlibris KNM se současnou signaturou. Na ff. 2r, 235r černé kruhové razítko KNM. Na fol. 235r přírůstkové číslo KNM 4/2019 a KNM2 6102. Do KNM byl rukopis zakoupen 5. 4. 2019 z antikvariátu Ztichlá klika a dle sdělení antikváře Jana Placáka byl součástí knihovny literárního historika Bedřicha Slavíka (1911-1979).

1r: „Analogia totius familiae Orlikianę ab atavis abavis et avis usque ad moderna tempora. Anno Domini 1653 
a Joanne Christophoro Orlik libero baronę Laziska, praelato cathedralis ecclesiae Olomucensis canonico, prothonotario apostolico, domino in Sednitz, Leutersdorff, serenissimi archiducis Leopoldi episcopi Olomucensis consiliario, decano Mezeritz ad Beczwam“

Souhrnný titul dvou následujicích dèl.

3r-92v: [Jan Kryštof Orlík z Laziska:] „Ad illustres aquilas Orlikianas prosopopoeia“"

Dějiny původně polského šlechtického rodu Orliků z Laziska sepsané olomouckým kanovnikem a děkanem ve Valašském Meziřičí Janem Kryštofem Orlíkem z Laziska (1616-1667) pro potomky jeho bratra Stanislava Jeronýma († 1669). Historie počátků rodu v Polsku je ličena souhrnně, po presídlení rodu na Moravu po jednotlivcích. Podrobnější záznamy se vztahuji predevším k první polovině 17. století. Nejmladši se váže k roku 1655, v prripiscich k roku 1666. Součástí textu jsou i opisy několika k Orlikưm se vážících listin. Krodu i zmíněným jednotlivcưm viz MA ̌́EK 2010, s. 40.

96r-193r: [Jan Kryštof Orlík z Laziska:] „Ad illustres aquilas Orlikianas prosopopoeia“

Stejné dílo jako text výše, reflektuje však opravy v něm provedené a je doplněno o elogia na bájná polská knížata, skutečné polské panovníky Měška I., Boleslava I., Zikmunda III. Vasu a Vladislava IV. Vasu i část jejich př́buzných a hodnostářu (ff. 96v-123r).

197r-235r: Casimirus Vincentius Chřanowski de Zarebie: „Aetas triplex pervetustae familiae liberorum baronum Orlik de Laziska in Bohemia, Polonia et provinciis Austriacis per saecula duodecim feliciter producta, nec tam mensibus et annis, quam gloriose et heroice gestis distincta in senio etiam aucta dignitate, honore et felicitate vigens, virens, florensque cuius illustres memorias etsi non omnes, nec in omnibus, aliquas tamen in quibusdam historicis earundem provinciarum observatas, extraxit et in lucem produxit Casimirus Vincentius Chřanowski de Zarebie parochus in Zacraw diecesis Wratislaviensis 1710“"

Déjiny šlechtického rodu Orliků z Laziska (o rodu viz komentár $k$ ff. 3r-92v). Spis uvozuje dedikace olomouckému kanovníkovi Karlu Juliovi Orlikovi z Laziska (1651-1716) na ff. 198r-199r. Vlastní výklad je rozdělen na tři věky. První věk rozdělený na osm oddili pojednává o pưvodu rodu v Čechách, pričemž s Orlikky spojuje lokality stejného jména a některé jejich držitele (ff. 200r-206v). Druhý věk o deseti oddilech popisuje jejich presídlení do Polska a tamní působení (ff. 207r-217v). Tretí věk se v patnácti oddilech věnuje historii Orliků v zemich Habsburské monarchie (obsahuje i rodokmen moravských Orliků na ff. 222v-223v) a jeho součástí je také výčet fundací a zbožných aktivit ve všech zemich jejich skutečného i domnělého pobytu (ff. 218r-235r).

\section{B 33}

střední Evropa, XVIII (post 1726), pap., 128 pp., $32,5 \times 21,5 \mathrm{~cm}$, vazba dobová

Původní paginace ve vnějším horním rohu. Zrcadlo vyznačeno na lichých stranách jednou linkou tužkou, vpichy patrné.

Písmo: psáno jednou písařskou rukou, latinskou humanistickou kurzivou. Text místy podtrhán (jde o pasáže v tisku

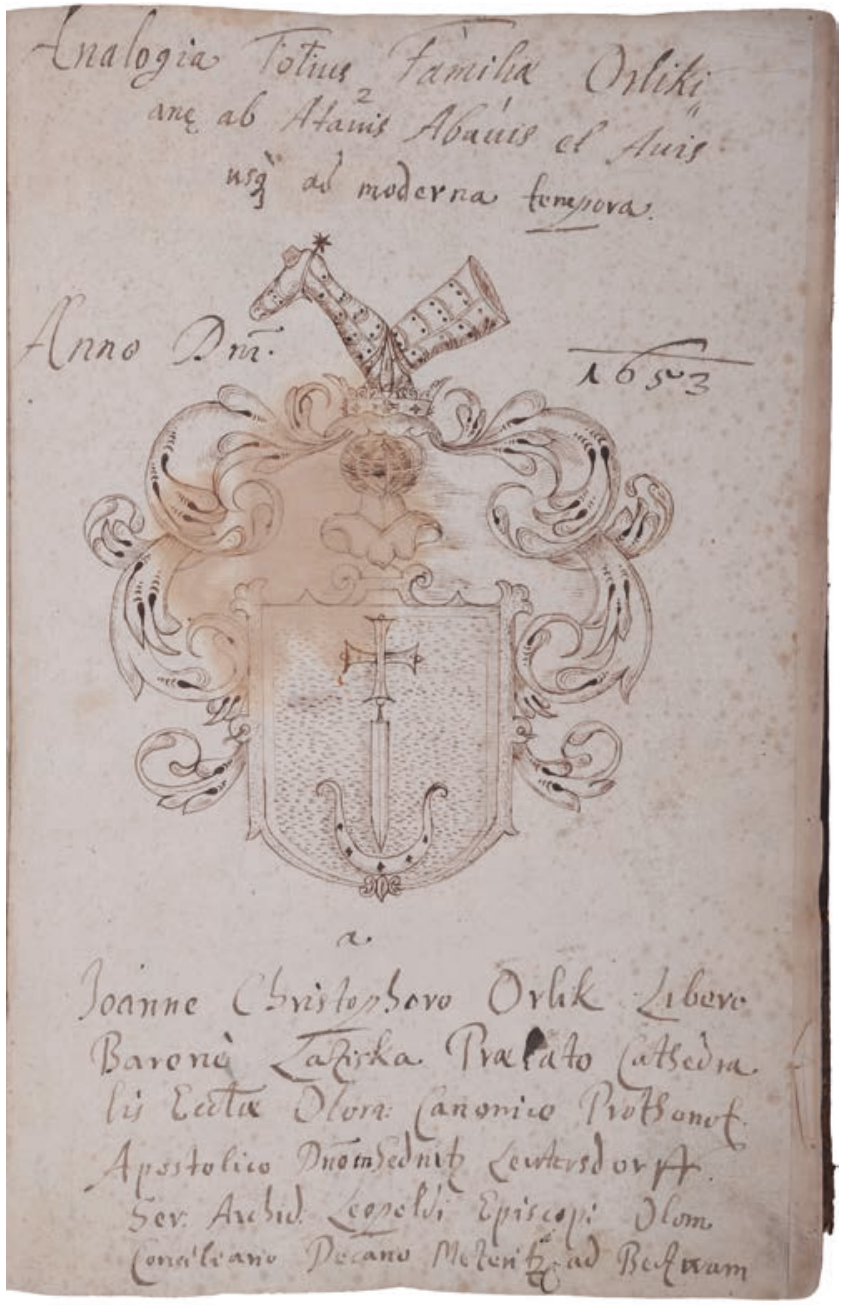

Obr. 6. Dějiny rodu Orlíků z Laziska. Praha, Knihovna Národního muzea, oddělení rukopisů a starých tisků, sign. VIII $D$ 36, fol. 1r, první list s perokresbou erbu Orlíků z Lazicka. Foto: KNM.

spisu sázené kurzivou, viz textový popis níže). Polokožená vazba, lepenkové desky potažené hnědým stř́kaným papírem se slepotiskovým jednolinkovým rámem. Hřbet potažen hnědou kůží. Šití na čtyři vazy. Vpředu jeden, vzadu dva listy předsádky. Na přední ořízce stopy po vpiších. Za pag. 56 vložen malý papírový útržek (záložka) se skvrnami od inkoustu. $Z$ přední desky se odlepuje papírový potah. Přední lepenková deska se rozlepuje, v makulatuře fragmenty latinského textu rukou 17.-18. století a německého rukou 16. století. Potah hřbetu poškozen na vícero místech, v horní části zcela chybí. Předsádky odlepené, z přední jeden list chybí, ze zadní jeden uvolněn. Knižní blok částečně uvolněn z vazby.

Na předním přídeští exlibris KNM se současnou signaturou. Na pp. 2, 128 černé kruhové razítko KNM. Na pag. 128 přirůstkové číslo KNM 4/2019 a KNM2 6104. Do KNM byl rukopis zakoupen 5. 4. 2019 z antikvariátu Ztichlá klika, do nějž byl dle sdělení antikváře Jana Placáka získán z Mnichova.

1-128: [Leopold Grim: Philosophia scholastico-ethica fulgidissimis Habspurgico-Austriacorum imperatorum virtutibus illustrata, theses] 
Padesát rozvinutých tezí filozofické disertačni práce obhájené Janem Karlem z Valdštejna a vydané roku 1726 v pražské jezuitské tiskárně (BCBT11236). Hlavním autorem textu je však v duchu dobové praxe pravděpodobně praeses disertace Leopold Grim (1688-1759), tehdejši profesor filozofie Karlo-Ferdinandovy univerzity (ČORNEJOVÁ FECHTNEROVÁ 1986, s. XXXIX, 128; $k$ jeho osobě a dílu TAMTÉŽ, s. 127-129). Oproti tisku postrádá rukopis titulní list, dedikaci císaři Karlu VI., úvody jednotlivých částí, elogia, kvestie, filozofické otázky a rejstřiky.

\section{B 67}

Čechy, XIX in., pap., 55 ff., $25 \times 19,5 \mathrm{~cm}$, vazba dobová

Moderní foliace provedena tužkou po deseti uprostřed dolního okraje během katalogizace (2020). Původní paginace 80 (recte 81 ), 28 pp. provedena inkoustem ve vnějším horním rohu s chybou v první části: pag. 26 opomenuta. Zrcadlo vyznačeno tužkou na vnějším okraji a linkováním. Fol. 55v prázdné. Okraje listů mírně roztřepené, některé listy zašpiněné.

Písmo: na sepsání rukopisu se podílely dvě písařské ruce, ruka A: ff. 1r-15v, 18r-55r, ruka B: ff. 16r-18r, obě německá novogotická kurziva, část nadpisů polokurzivou, ostatní nadpisy, některá slova latinského původu a zaklínací formule latinskou humanistickou polokurzivou. Místy krátké přípisky rukou A a asi dvěma dalšími. Výzdoba: astrologické a magické symboly na ff. 3v, 10r, 17r, 17v, 19v, 20r, 21r, 25v, 28v, 31r, 32v, 36v. Měkká papírová vazba ze dvou papírů prošitých provázkem. Vnitřní strana hřbetu vyztužena papírem. Šití dlouhými stehy. Na obou přídeštích vymalovány části magického kruhu provedeného červenou barvou. Na předním s nápisem ,nai“ (zbytek Adonai?) a dva kř́že (jeden poškozen), na zadní dva symboly, jeden podobný dlouhému s, druhý $\mathrm{T}$. Na hřbetní výztuze fragment tištěného rámu s textem „Ordinär gebeitzter Schnupftabak“ a německých prrípisků inkoustem dobovou rukou. Rukopis byl ambulantně opraven v roce 2018 Janem Novotným v restaurátorské dílně KNM (očištění, spravení trhlin).

Na přední desce nápis „Klíč Klavikula filii Davides [!]“ a poznámka „Repara“ s datem 1. 5. 1846, oboje inkoustem. Za fol. 54 vložen lístek o rozměrech $15 \times 8,5 \mathrm{~cm}$, na jedné straně poznámky k zaklínání a magické symboly, na druhé straně magické symboly a novější špatně čitelný text fialovou pastelkou. Na zadním přídeští exlibris KNM se současnou signaturou. $\mathrm{Na}$ fol. $55 \mathrm{v}$ černé kruhové razítko KNM, přirůstkové číslo KNM 2/2017 a KNM2 6087. Do KNM byl rukopis zakoupen 16. 8. 2017 od Niny Iris ze Sušice.

\section{1r-1v, 41r: [Poznámky]}

Odkazy na část obsahu, poznámky, zkoušky pera. Převážně ruka A, ale i několik dalšich.

2r-39r: „Klíč Šalamounův syna Davidova“

České znění grimoáru Clavicula Salomonis. Z četných variant tohoto spisu je nejpodobnějši latinské verzi zachycené např. v tisku Clavicula Salomonis Filii David, [s. l.: s. t., 1690?] (VD17 15:743562E). Spis je rozdělen do dvou knih. První obsahuje návody na zaklínání duchi̊, druhá popisuje $k$ tomu potrebné očistné postupy, oblečení

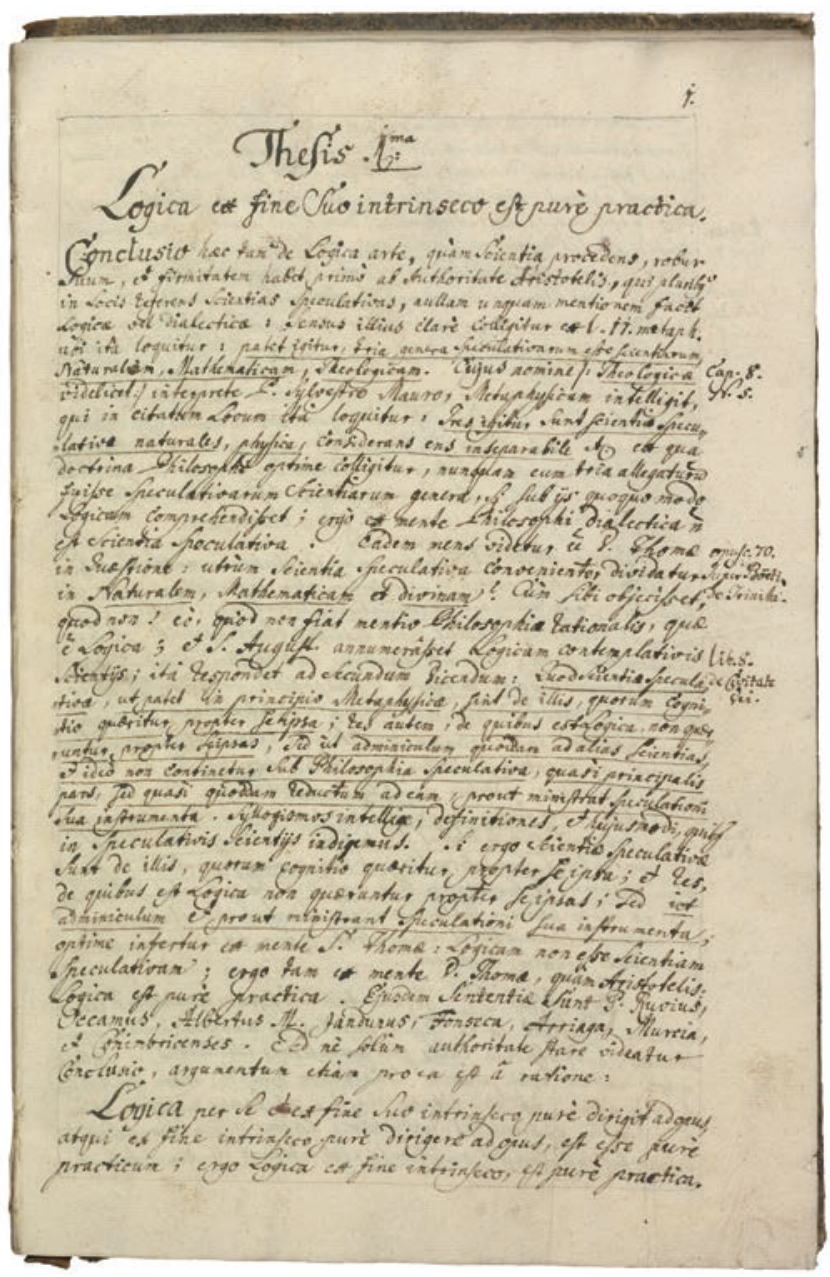

Obr. 7. Leopold Grim: Philosophia scholastico-ethica. Praha, Knihovna Národního muzea, oddělení rukopisů a starých tisků, sign. X B 33, pag. 1, první list. Foto: KNM.

a predměty. Z prvni knihy je oproti zmíněné latinské verzi několik zaklínání vypuštěno. Rukopis stejného znění se nachází v KNM, III D 34 (BARTOŠ 1926, č. 629).

39v-40v: „Tajemství jména Božího, jejš následující 72 národové ze čtyřmi písmenami píší a jmenují“

Seznam údajných čtyřxismenných znění slova bůh v jazycích 72 národì. První národ je uveden česky: „, Abyssinšti“", ostatni německy (zmíněni jsou i Čěsi: „Böhmer Bueg“). Společně s Clavicula Salomonis se tento text obvykle nevyskytuje, v čistě německém podání je ale součástí výše citovaného tisku. Podle neupřesnéného zdroje seznam vydal SCHEIBLE 1846, s. 283-285.

41v-55r: [Klíč Šalamounův, část první knihy]

Osm zaklínání z prvni knihy české verze Clavicula Salomonis. Jedná se o zaklináni vypuštěná z textu v první části rukopisu, viz komentár̆ kff. 2r-39r.

\section{G 1}

Čechy (Praha), 1624, pap. + perg., 272 ff., $9 \times 5,5 \mathrm{~cm}$, vazba soudobá

Ff. 1-2 pergamen, zbytek papír. Starší foliace inkoustem vyznačena pouze vlevo dole na fol. 123v, moderní doplněna tužkou dole uprostřed po deseti během katalogizace (2020). 


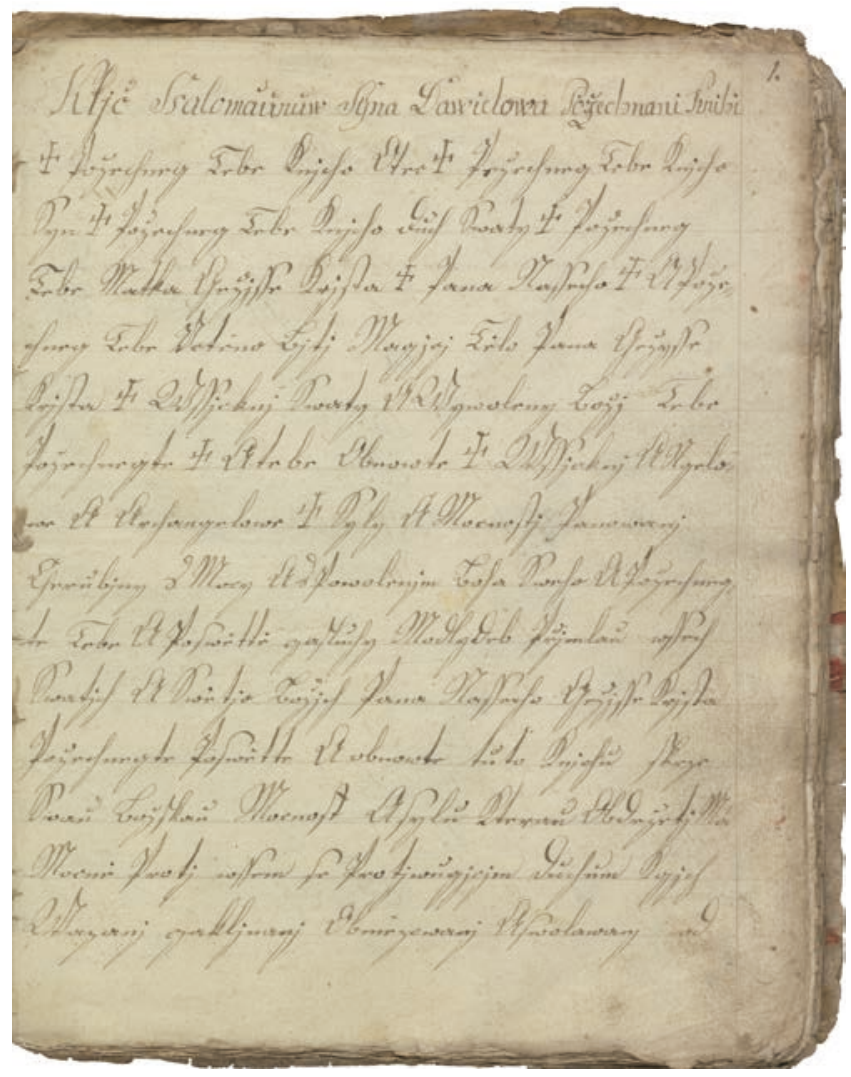

Obr. 8. Klíč Šalamounưv syna Davidova. Praha, Knihovna Národního muzea, oddělení rukopisů a starých tisků, sign. XI B 67, fol. 2 r, začátek spisu. Foto: KNM.

Reklamanty na koncích složek. Textové zrcadlo ohraničeno trojitou linkou $\mathrm{s}$ ornamentálním zdobením červeným inkoustem ve stylu rámů z tiskařských ozdůbek v soudobých tiscích, na fol. 203r provedeno inkoustem a doplněno inkoustovým a zlatým šrafováním. Ff. 1r, 203-204, 267r prázdná. Některé listy mírně natrženy.

Písmo: jedna písařská ruka píšící českou novogotickou polokurzivou. Výzdoba: zlacený titulní list v borduře ve stylu soudobých tisků na fol. 2r. Pletencové viněty na ff. 194r, 195r, 196v, 200v a 203r. Rubrikace, místy obtahovaná zlatě. Drobné iniciály červeně. Celokožená vazba zdobená slepotiskovým rámečkem se stopami zlacení na zadní desce. Dřevěné desky. Hřbet zdoben slepotiskovými linkami podél vazů a kapitálků. Šití na tři vazy, kapitálky lepené s jednoduchým obšíváním světlou a modrou nití. Na ořízce pozůstatky zlacení. Dva volné listy předsádky vpředu i vzadu, vnitřní dvoulist z mramorovaného papíru. Zadní listy předsádky započítány do foliace. Soudobé zasouvací pouzdro z lepenky potažené modrým moiré papírem. Desky a horní rohy mírně poškozeny ztrátou materiálu, hřbet lehce deformován, prasklé vnitřní drážky.

$\mathrm{Na}$ fol. 1r mladší přípisek „Georgii Streyc Zabresky“. $\mathrm{Na}$ fol. $2 \mathrm{r}$ „Ex libris Antonii Alesh (?)“. Na předním př́ídeští exlibris KNM se současnou signaturou. Na ff. 2v, 272r černé kruhové razítko KNM. Na fol. 272r přírůstkové číslo KNM 11/2018 a KNM2 6098. Do KNM byl rukopis zakoupen 30. 5. 2018 od Štefana Holčíka z Bratislavy.

2r-202v: Jiří Strejc: „Žalmové aneb zpěvové svatého Davida, kterýchž církev svatá, i stará i nová, při službě Boží vůbec i jinde obzvláštně vždycky s mnohým prospěchem užívala, v rytmy české vyložení a v způsob zpívání k vzdělání čistého náboženství právě sloužící, zformováni od Jiříka Strejce Z. MDCXXIIII.“"

Žalmové parafráze bratrského kněze, prekladatele a básnika Jiřiho Strejce (1536-1599) ve zněni třetí kralické redakce prvně doložené ve vydání bratrského kancionálu z roku 1615 (K12871). Titul je však formulován ve variantě známé z nekralických vydání a připojena je rovněž u těchto vydání obvyklá parafráze Desatera (ff. 196v-197r). Z rámcových částí rukopis obsahuje pouze „Poznamenáni některých žalmův, kteřiž se v melodijích srovnávajï“ (ff. 197v-198v) a , Rejistř́k ukazujicí, jak se kterýžalm počiná a koliký jest" (ff. 199r-202v). Snad se jedná o opis nedochovaného tisku. Na fol. 202v kolofon „Přepsáni v Starém Městě pražském v pondělí XIV. dne měsice řijna léta věku posledního MDCXXIIII. “. Edice předchozich redakci a jejich rozbor: STREJC 2014.

205r-266v: „Modlitby křest'anské každodenní, ranní a večerní, na dva téhodny rozdělené, $\mathrm{k}$ nimž jsou i jiné ke dnům suchým neb modlitebným, též k časům obzvláštním př́ípadné připojeny a napsány. Léta Páně MDCXXIIII.“

Iv, 267v-272r: [Poznámky, modlitby]

Jména, data a dvě modlitby rukou 18. století. Zmíněn „Joanes Simon “, dvakrát ,, Michael Simon“ (jednou s datem „, die 3. augusti 1790“), a „Josephus Simon“.

\section{Prameny:}

\section{Rukopisy:}

KNM, III D 34: Knihovna Národního muzea. Sbírka rukopisů, sign. III D 34 .

MZK, CH-RKP-79: Moravská zemská knihovna v Brně. Sbírka rukopisů, sign. CH-RKP-79.

MZK, CH-RKP-88: Moravská zemská knihovna v Brně. Sbírka rukopisů, sign. CH-RKP-88.

SOkA Kolín, knihovna, sign. 10849 R 1159: Státní okresní archiv Kolín. Knihovna, sign. 10849 R 1159.

\section{Staré tisky:}

BCBT03020: WEINGARTEN, Jan Jakub. Codex Ferdinandeo-Leopoldinus: Worinnen alle durch funffzig Jahr mit grosser Mühe und Unkosten gesammeltund von Anno 1600 allergnädigist ergangene respective Kayserliche Declaratorien, Rescripten, Kayserlich- und Königliche, Statthalterische, auch von hohen Obrigkeiten emanirte Patenten, und Decreten, etwelche Extracten der Landtägschlüssen, Königliche Instructiones, Privilegia, Landesordnungen,Erbvereinigungen mit der Cron Böheimb, und Novellen de Anno 1640 vollständig, einige aber remissive auff vorhero außgangenen Büchern sich beziehend, das Erbkönigreich Böhmen, Ertzhertzogthumb Oesterreich, Marggraffthumb Mähren, und Hertzogthümber Ober- und Niederschlesien, Publica, Politica, Militaria, auch das Justitzweesen in civilibus \& criminalibus betreffende Sachen enthalten, und zu finden seynd. Und dieses alles secundum seriem annorum \& mensium cum suo indice pro utilitate pub- 


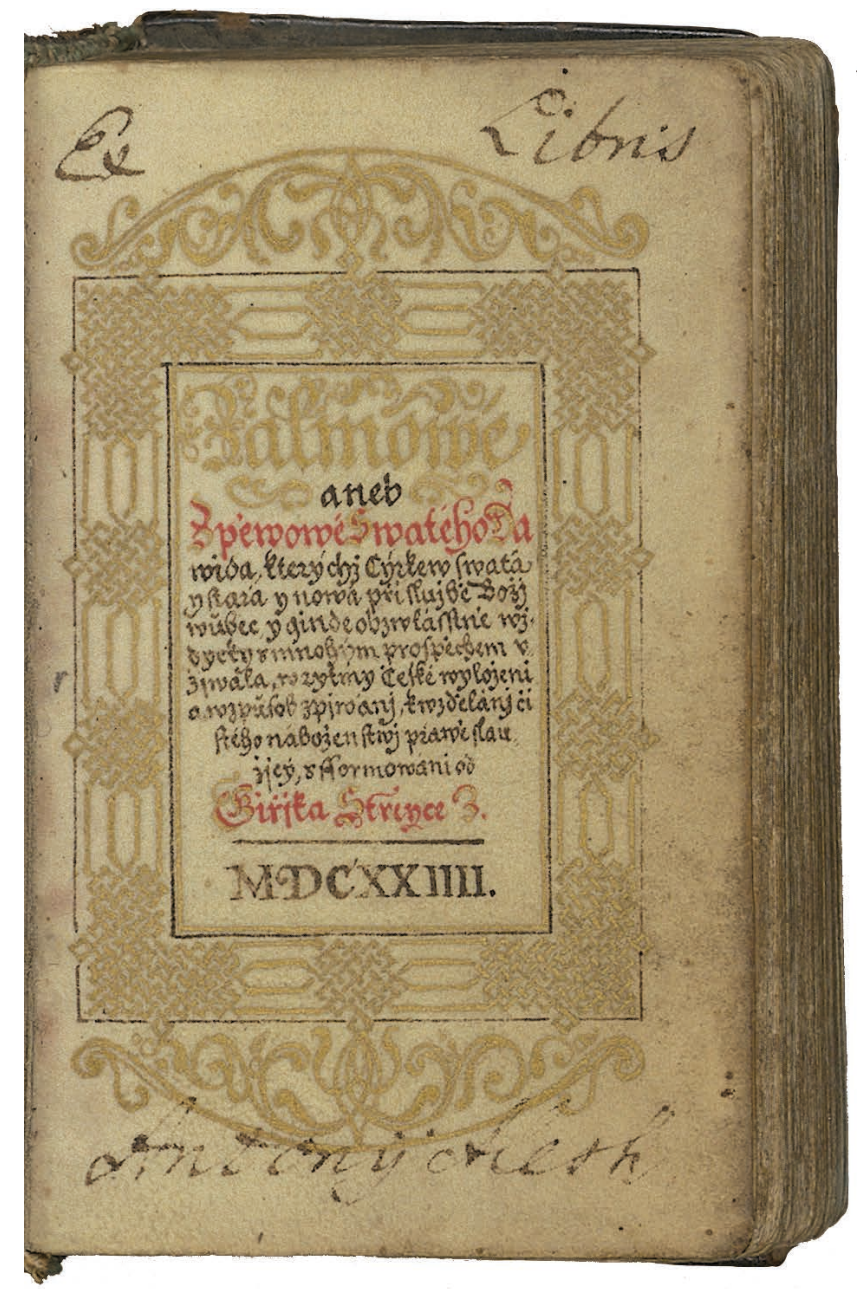

Obr. 9. Jiří Strejc: Žalmové aneb zpěvové svatého Davida; modlitby. Praha, Knihovna Národního muzea, oddělení rukopisů a starých tisků, sign. XVIII G 1, fol. 2r, titulní list žalmových parafrází Jiřího Strejce s exlibris Antonína Aleše (?). Foto: KNM.

lica gefertiget. Von Der Römis: Kayserl: auch zu Hungarn und Böheimb Königlichen Majestät Appellationsrath und Teütschen Secretario allda Joanne Jacobo Equite de \& in Weingarten, Praha: Karel Ferdinand Arnolt z Dobroslavína, 1701.

BCBT11236: GRIM, Leopold. Philosophia scholastico-ethica fulgidissimis Habspurgico-Austriacorum imperatorum virtutibus illustrata. Praha: Jezuitská tiskárna, 1726.

ib01219000: Ius municipale Moraviae, [Nürnberg: Georg Stuchs, cca 1498].

K01308: BRTVÍN z PLOŠKOVIC, Jan - ARTEMISIUS, Mikuláš - HUS, Jan. Hospodářr: Knižka velmi užitečná, zavírajic v sobě předně navedení života krest'anského, jak by ti, kteřiž v světě nad jinými panují, sami sebe i sobě poddané spravovati měli; potom gruntovní správu a pořádek všelijakého hospodářství, zvláště při panstvích a zbožich, potřebná pánům, kteřiž veliké statky na zemi mají. Praha: Daniel Adam z Veleslavína, 1587.

K12871: Písně duchovni evangelistské z Písem svatých a v nich zavřeného Božiho učeni složené, z přičin hodných opět bedlivě prehlédnuté, a jakož predně ke cti a chvále věčného Boha, v Trojici blahoslavené, tak potom k spasitedlnému Církví Jezukristových v národu českém i jiných, jazyku českému rozumějícich v víre Boži vzdělání a utvrzení vydané léta MDCXV. Přidáni jsou k nim žalmové Davida s. v rytmy a zpěvy pobožné, zformovaní. [Kralice: Bratrská tiskárna], 1615.

K19028: ZYVALDA, Jindřich Václav. Dejm města Kouřima, někdy čtverou vioni z sebe vydávající. [Praha?: Jezuitská tiskárna?, 1659 nebo 1665?].

VD17 1:041834T: KRISTIÁN z KOLDÍNA, Pavel, Das Bohmische Stadtrecht. Wie dasselbe in drey Prager, auch anderen Städten des Königreichs Böhaimb, täglich observiret und löblich gehalten wird. Kurtz zusammen gezogen, in ordentliche Tittel verfasset, und in Teutsche Sprache versetzet. Leipzig: Johann Hermann, 1614.

VD17 15:743562E: Clavicula Salomonis Filii David. [s. 1.: s. t., 1690?].

\section{Edice:}

BRANDL 1872: BRANDL, Vincent (ed.). Libri citationum et sententiarum seu Knihy pưhonné a nálezové I. Brunae: Deputationis March. Mor., 1872.

BRANDL 1873: BRANDL, Vincent (ed.). Libri citationum et sententiarum seu Knihy půhonné a nálezové II. Brunae: Deputationis March. Mor., 1873.

BRANDL 1880: BRANDL, Vincent (ed.). Libri citationum et sententiarum seu Knihy pưhonné a nálezové III/2. Brunae: Deputat. March. Mor., 1880.

BRANDL 1882: BRANDL, Vincent (ed.). Libri citationum et sententiarum seu Knihy půhonné a nálezové IV/2. Brunae: Deputat. March. Mor., 1882.

FLODR 1990: FLODR, Miroslav. Právní kniha města Brna $z$ poloviny 14. století. I. Úvod a edice. Brno: Archiv města Brna, 1990.

FRIEDBERG - RICHTER 1959: FRIEDBERG, Emil RICHTER, Aemilius Ludwig. Corpus Iuris Canonici. Pars prior. Graz: Akademische Druck- und Verlagsanstalt 1959.

SCHEIBLE 1846: SCHEIBLE, Johann. Das Kloster. Weltlich und geistlich. Meist aus der ältern deutschen Volks-, Wunder-, Curiositäten-, und vorzugsweise komischen Literatur III. Stuttgart: [s. n.], 1846.

STREJC 2014: MATĚJEC, Tomáš (ed.). STREJC, Jiří. Žalmové neb zpěvové svatého Davida. Žalmové parafráze Jiřiho Strejce podle vydání z roku 1598 s variantami podle vydání z let 1587 a 1596. Praha: Strahovská knihovna, 2014.

\section{Literatura:}

BARTOŠ 1926: BARTOŠ, František Michálek. Soupis rukopisů Národního musea v Praze. Svazek I. Praha: Melantrich, 1926.

BARTOŠ 1927: BARTOŠ, František Michálek. Soupis rukopisů Národního musea v Praze. Svazek II. Praha: Melantrich, 1927.

BENEŠ et al. 2015: BENES̆, Jiří et al. Rukopisné zlomky Knihovny Národního muzea: Signatury 1 B a 1 C. Praha: Národní muzeum, Scriptorium, 2015.

BRČÁK et al. 2014: BRČÁK, Marek et al. Rukopisné zlomky Knihovny Národního muzea: Signatura 1 A. Praha: Národní muzeum, Scriptorium, 2014. 
BROM et al. 2016: BROM, Vlastimil et al. Rukopisné zlomky Knihovny Národního muzea: Signatury 1 D, 1 E a $1 G$. Praha: Národní muzeum, Scriptorium, 2016.

ČÁDA 1958: ČÁDA, František. Sborníky moravských půhonů a nálezů. In: BERAN, Jiří (ed.). Akademiku Václavu Vojtíškovi k 75. narozeninám. Praha: Archiv Československé akademie věd, 1958, s. 35-57.

ČORNEJOVÁ - FECHTNEROVÁ 1986: ČORNEJOVÁ, Ivana - FECHTNEROVÁ, Anna. Životopisný slovnik pražské univerzity: filozofická a teologická fakulta 1654-1773. Praha: Univerzita Karlova, 1986.

DOKOUPIL - ŠTACHOVÁ 2011: DOKOUPIL, Vladislav - ŠTACHOVÁ, Nad'a. Soupis rukopisů zámecké knihovny hrabat Chorinských z Veseli nad Moravou. Brno: Moravská zemská knihovna, 2011.

DRAGOUN 2011: DRAGOUN, Michal. Soupis středověkých rukopisů Knihovny Národního muzea. Doplňky ke katalogům F. M. Bartoše, J. Vašici a J. Vajse. Praha: Národní muzeum, Scriptorium, 2011.

DRAGOUN 2017: DRAGOUN, Michal. Rukopisné zlomky Knihovny Národního muzea: Signatura $1 \mathrm{~K}$ (Dodatky ke sbirkám Adolfa Patery a Čeňka Zíbrta). Praha: Národní muzeum, Scriptorium, 2017.

DRAGOUN - MAREK 2012: DRAGOUN, Michal MAREK, Jindřich. Rukopisné zlomky Knihovny Národního muzea: Sbirky Adolfa Patery a Čeňka Zibrta. Praha: Národní muzeum, Scriptorium, 2012.
MAIELLO 2012: MAIELLO, Giuseppe. Racionalismus Karla Ferdinanda Schertze a Magia posthuma. Slavica Litteraria 15, 2012, č. 2, s. 215-222.

MAŠEK 2010: MAŠEK, Petr. Šlechtické rody v Čechách, na Moravě a ve Slezsku. Od Bílé hory do současnosti. Díl II (N-Ž). Praha: Argo, 2010.

MUCHKA 2019: MUCHKA, Pavel. Nové sbírkové akvizice v Knihovně Národního muzea v roce 2019. Acta Musei Nationalis Pragae - Historia litterarum 64, 2019, č. 1-2, s. $76-80$.

SVOBODOVÁ 2012: SVOBODOVÁ, Milada. Rukopisy ze sbirek Tomáše Antonína Putzlachera, Michaela Schustera a dalšich nešlechtických bibliofilù ve fondu pražské lobkowické knihovny v Národní knihovně České republiky. Svazek I-II. Praha: Národní knihovna České republiky, 2012.

ZÁSADY: Zásady popisu rukopisů [online]. Masarykův ústav a Archiv AV ČR, v. v. i. Oddělení pro soupis a studium rukopisů. [Cit. 10. 2. 2020]. Dostupné z: https://www.mua. cas.cz/sites/default/publicFiles/SOUBORY/2015/09/22/ 11-22-33/rkp_zasady.pdf

\section{| Zdeněk Mužík}

Knihovna Národního muzea

oddělení rukopisů a starých tisků

Václavské náměstí 68

11000 Praha 1 